\title{
Lecture Notes in Mechanical Engineering
}

\section{Series Editors}

Francisco Cavas-Martínez, Departamento de Estructuras, Universidad Politécnica de Cartagena, Cartagena, Murcia, Spain

Fakher Chaari, National School of Engineers, University of Sfax, Sfax, Tunisia

Francesco Gherardini, Dipartimento di Ingegneria, Università di Modena e Reggio Emilia, Modena, Italy

Mohamed Haddar, National School of Engineers of Sfax (ENIS), Sfax, Tunisia

Vitalii Ivanov, Department of Manufacturing Engineering Machine and Tools, Sumy State University, Sumy, Ukraine

Young W. Kwon, Department of Manufacturing Engineering and Aerospace Engineering, Graduate School of Engineering and Applied Science, Monterey, CA, USA

Justyna Trojanowska, Poznan University of Technology, Poznan, Poland

Francesca di Mare, Institute of Energy Technology, Ruhr-Universität Bochum, Bochum, Nordrhein-Westfalen, Germany 
Lecture Notes in Mechanical Engineering (LNME) publishes the latest developments in Mechanical Engineering-quickly, informally and with high quality. Original research reported in proceedings and post-proceedings represents the core of LNME. Volumes published in LNME embrace all aspects, subfields and new challenges of mechanical engineering. Topics in the series include:

- Engineering Design

- Machinery and Machine Elements

- Mechanical Structures and Stress Analysis

- Automotive Engineering

- Engine Technology

- Aerospace Technology and Astronautics

- Nanotechnology and Microengineering

- Control, Robotics, Mechatronics

- MEMS

- Theoretical and Applied Mechanics

- Dynamical Systems, Control

- Fluid Mechanics

- Engineering Thermodynamics, Heat and Mass Transfer

- Manufacturing

- Precision Engineering, Instrumentation, Measurement

- Materials Engineering

- Tribology and Surface Technology

To submit a proposal or request further information, please contact the Springer Editor of your location:

China: Ms. Ella Zhang at ella.zhang@springer.com

India: Priya Vyas at priya.vyas@ springer.com

Rest of Asia, Australia, New Zealand: Swati Meherishi

at swati.meherishi@springer.com

All other countries: Dr. Leontina Di Cecco at Leontina.dicecco@springer.com

To submit a proposal for a monograph, please check our Springer Tracts in Mechanical Engineering at http://www.springer.com/series/11693 or contact Leontina.dicecco@springer.com

Indexed by SCOPUS. All books published in the series are submitted for consideration in Web of Science.

More information about this series at http://www.springer.com/series/11236 
Sadhan Kumar Ghosh · Koushik Ghosh .

Santanu Das · Pranab Kumar Dan · Arijit Kundu

Editors

Advances in Thermal

Engineering, Manufacturing, and Production Management

Select Proceedings of ICTEMA 2020

Springer 


\section{Editors}

Sadhan Kumar Ghosh

Department of Production Engineering

and Management

Jadavpur University

Kolkata, West Bengal, India

\section{Santanu Das}

Kalyani Government Engineering College

Kalyani, West Bengal, India

\author{
Arijit Kundu \\ Department of Thermal Engineering \\ Jalpaiguri Government Engineering College \\ Jalpaiguri, West Bengal, India
}

\author{
Koushik Ghosh \\ Department of Thermal Engineering \\ Jadavpur University \\ Kolkata, West Bengal, India
Pranab Kumar Dan
Department of Production Management Indian Institute of Technology Kharagpur Kharagpur, West Bengal, India

\author{
ISSN 2195-4356 \\ Lecture Notes in Mechanical Engineering \\ ISBN 978-981-16-2346-2 ISBN 978-981-16-2347-9 (eBook) \\ https://doi.org/10.1007/978-981-16-2347-9
}

(C) The Editor(s) (if applicable) and The Author(s), under exclusive license to Springer Nature

Singapore Pte Ltd. 2021

This work is subject to copyright. All rights are solely and exclusively licensed by the Publisher, whether the whole or part of the material is concerned, specifically the rights of translation, reprinting, reuse of illustrations, recitation, broadcasting, reproduction on microfilms or in any other physical way, and transmission or information storage and retrieval, electronic adaptation, computer software, or by similar or dissimilar methodology now known or hereafter developed.

The use of general descriptive names, registered names, trademarks, service marks, etc. in this publication does not imply, even in the absence of a specific statement, that such names are exempt from the relevant protective laws and regulations and therefore free for general use.

The publisher, the authors and the editors are safe to assume that the advice and information in this book are believed to be true and accurate at the date of publication. Neither the publisher nor the authors or the editors give a warranty, expressed or implied, with respect to the material contained herein or for any errors or omissions that may have been made. The publisher remains neutral with regard to jurisdictional claims in published maps and institutional affiliations.

This Springer imprint is published by the registered company Springer Nature Singapore Pte Ltd.

The registered company address is: 152 Beach Road, \#21-01/04 Gateway East, Singapore 189721, Singapore 
Green Business in Blue Economy: Quality Management and Development of Innovative Products

Nataliia Kraus, Kateryna Kraus, and Valerii Osetskyi

New Heuristics to Minimize Makespan of Permutation Flowshop

Scheduling Problem with Uniformly Distributed Processing Times

Rose Dhar, Alok Mukherjee, Kingshuk Chatterjee, and Partha Haldar 


\title{
Green Business in Blue Economy: Quality Management and Development of Innovative Products
}

\author{
Nataliia Kraus, Kateryna Kraus, and Valerii Osetskyi
}

\section{Introduction}

Ukraine ranked 60th in Global and Digital Competitiveness Rankings IMD-2017 [1, 2] of the International Institute for Management Development (IMD).

However, in digital competitiveness ranking for the implementation and study of digital technologies that are transformative in government practice, business models and society as a whole, Ukraine is in the last positions alongside Indonesia, Mongolia, Peru and Venezuela. Innovation has become a major factor in the success of states and businesses today.

Countries and corporations seeking to become world economic leaders are investing heavily in research and development, new manufacturing and quality management. Among the countries that invest the largest share of their GDP in research and development (R\&D), South Korea leads by a large margin of $4.3 \%$ and Israel of $4.1 \%$. Japan invests $3.6 \%$ of GDP, Austria, Germany and Switzerland-about $3 \%$. Whereas, by comparison, Ukraine invests only $0.2 \%$ of its already insignificant GDP in scientific development.

In terms of money in R\&D investment, in purchasing power parity, the absolute leader is the US $-\$ 480$ billion and China $-\$ 371$ billion a year. For comparison, in

\footnotetext{
N. Kraus

Department of Finance and Economics, Borys Grinchenko Kyiv University, Kiev, Ukraine e-mail: k2205n@ukr.net

K. Kraus (凶)

Department of Management, Borys Grinchenko Kyiv University, Kiev, Ukraine

e-mail: k23k@ukr.net

\section{Osetskyi}

Department of Economic Theory, Macro-and Microeconomics, Taras Shevchenko National University of Kyiv, Kiev, Ukraine

e-mail: val_osetski@ukr.net
} 
Ukraine- $\$ 2.5$ billion. Expenditure on R\&D 1000 corporations, the world's largest R\&D investor, increased $3.2 \%$ in 2017 to $\$ 702$ billion.

In 2017, the Government of Ukraine presented a National Report on "Sustainable Development Goals: Ukraine" [3], which set the benchmarks for achieving them. However, there are now many concepts that are based on utility estimates such as energy, water, waste management, transportation and complicate long-term smart community planning.

The European Strategy for Intellectual, Sustainable and Inclusive Development by 2020 [4] has declared the achievement of objectives as a common interest on the basis of three complementary economic policy priorities: smart growth (economic development based on knowledge and innovation); sustainable development (promoting a more resource-saving, green and competitive economy); inclusive growth (stimulating the employment economy, ensuring social and territorial cohesion).

\section{Green Business}

\subsection{The Essence of Implementing Green Business}

Valuable in the scientific sense of the study of green entrepreneurship are scientific works and practical achievements of such well-known scientists as Gryunwald [5], Merts et al. [6], Shchulst. The theory concerning the future modern development of the economy, the so-called "blue economy" theory, by a scientist economist, a member of the Roman Club of G. Pauli, deserves due attention.

Economists from Ukraine are also actively involved in research and development in the field of doing business [7], which seeks to combine environmental concerns, fair treatment of employees and economic success and the issues of quality management of environmental business. Among them are the names of V. Heits, V. Galasyuk, A. Grytsenko, O. Lanovenko, O. Ostapishyna, I. Yurinova. But at the same time, there are a number of pressing issues of type:

- The particularities of problems and risk management at the various stages of green business in blue economy;

- Previous recommendations regarding the control and quality management of green production at the stage of its growth;

- Ranking of the most promising green business ideas that allow us to join green market and lay the foundations for the development of blue economy in Ukraine remains poorly understood.

The purpose of the article is to study the features of green business in blue economy. Presentation of the core of VI-th and VII-th technological structures that lay foundations for the establishment of green business in blue economy. 
Finding out the specificities of problems and risk management in the various stages of green business in blue economy. Substantiation and disclosure of previous recommendations regarding the control and quality management of green production at the stage of its growth.

Green business (sustainable business) or circular (non-exhaustive) business is an activity that has minimal adverse impact on the global or local environment, society or economy - a business that seeks to combine environmental, equitable treatment and economic success [8]. Most green companies have progressive environmental principles and policies on human issues. A business is generally considered green if it meets the following four criteria:

- Is guided by the principle of "circulation" in making all its business decisions;

- Supplies environmental goods or services that replace the demand for nonenvironmental goods or services [9];

- "Greener" than typical competitors;

- Has long been committed to environmental standards.

The Brundtland Commission [10] emphasized that the understanding of inexhaustibility rests on three pillars: people, the planet and profit. Circular business in its content aims to balance these three factors, using circular production and distribution in order to influence the environment, economic development and society [11].

In general, all types of businesses affect circulation in the context of world market and our planet in some sense. The development of a circular principle in business can be significant for the buyer, the investor, and it is also environmentally friendly. The circular business must meet the needs of the buyer and be environmentally friendly.

A scientist economist, a member of the Roman Club G. Pauli put forward his theory about the future of the latest economic development, the so-called blue economy theory. Her content was revealed in her research paper entitled "Blue Economy: 10 Years, 100 Innovations, 100 Million Jobs".

In her research, the scientist is devoted to the aspects of becoming an innovative economy in the context of the transition of society to sustainable environmentally sound development. G. Pauli argues that economic development and the restoration of environmental balance must be interrelated processes [12].

\subsection{Blue Economy}

The author has found innovative solutions to the pressing problems of humanity. G. Pauli's scientific postulate is that "there is nothing superfluous in nature", so the rational use of resources at every stage of humanity's economic activity is a necessary condition for humanity's competitiveness.

"Blue economy" demonstrates how many environmental and environmental degradation problems can be avoided through the conservation of material resources 
and the adaptation of production processes to the laws of nature. G. Pauli gives examples of the interrelationship between nature and economy and points to the ways of harmonious environmental and economic development of society.

Based on the existing concept of green business, which is based on the principle of "circulation" and theory, regarding the future modern development of the economy, the so-called blue economy theory, it can be stated that their implementation in practice pursues the same goal, namely: a consistent and reasonable combination of economic and environmental development on a circular basis in business with complete satisfaction of the customer's needs.

For these reasons, we consider it appropriate to present the core of VI and VII technological frameworks that lay foundations for green business formation in blue economy, which are presented in Table 1.

Regarding the functions performed by green business, most of them relate to all possible lines of business. For example, setting prices for goods and services sold, conducting research and development work and creating innovative goods, methods and technologies, creating new jobs.

\subsection{Problems of Green Business in Blue Economy}

Functions specific only to green business entities include: meeting public needs for environmentally friendly products, protecting the environment, minimizing environmental-destructive environmental impacts, shaping the environmental awareness of society and its environmental culture, and preserving natural capital. It is the fulfilment of these functions that distinguishes green business in blue economy, among other areas of activity.

It should be noted that the functions that are inherent in all areas of activity in the green business are manifested in a more environmentally rational way. For example, an efficient use of resources not only minimizes the amount of their use, but also is based on the choice of those resources, and the use of which will have the least possible environmental impact [8].

Specific features of problems and risk management at the various stages of green business in blue economy are presented in Table 2 .

\subsection{Green Products in Blue Economy}

Previous recommendations regarding the control and quality management of green production at the stage of its growth are presented in Table 3. The forms of manifestation of green production today are: eco-company; direct green entrepreneurship; production of environmental goods and services.

The first form of green production is the introduction of environmental management, which is mainly related to the administrative regulation of the enterprises in 
Table 1 Core of VI and VII technological structures that lay for green business in blue economy [15, p. 57 and own experience]

\begin{tabular}{|c|c|c|}
\hline Direction & Problems solved & $\begin{array}{l}\text { Possible implementation } \\
\text { options }\end{array}$ \\
\hline \multicolumn{3}{|c|}{ Characteristics of VI technological way } \\
\hline Non-traditional energy & $\begin{array}{l}\text { Reducing the burden on the } \\
\text { environment, saving natural } \\
\text { resources }\end{array}$ & $\begin{array}{l}\text { Hydrogen energy, synthetic } \\
\text { fuel, solar energy converters, } \\
\text { closed-loop nuclear power } \\
\text { plants, fast reactors, vortex heat } \\
\text { generators }\end{array}$ \\
\hline Information systems & $\begin{array}{l}\text { Globalization of the world } \\
\text { economy through partnership }\end{array}$ & $\begin{array}{l}\text { Bioenergy, optics, } \\
\text { quantum-vacuum computers, } \\
\text { artificial intelligence, torsion } \\
\text { communication systems }\end{array}$ \\
\hline Biotechnology & A new level of well-being & $\begin{array}{l}\text { Water purification, seafood } \\
\text { desalination, modified } \\
\text { agro-culture, disease treatment, } \\
\text { cloning }\end{array}$ \\
\hline Transport & $\begin{array}{l}\text { Environmental safety, speed, } \\
\text { efficiency }\end{array}$ & $\begin{array}{l}\text { Underwater superliners, string } \\
\text { transport, electric vehicles, } \\
\text { aerospace transport systems }\end{array}$ \\
\hline Ecology & Sustainable development & $\begin{array}{l}\text { Waste-free and closed } \\
\text { technological "circuits" }\end{array}$ \\
\hline Materials & $\begin{array}{l}\text { Durability, safety, reliability, } \\
\text { efficiency }\end{array}$ & $\begin{array}{l}\text { Nanotechnology, amorphous } \\
\text { metals, memory materials, } \\
\text { high-temperature } \\
\text { superconductivity, torsional } \\
\text { materials processing } \\
\text { technologies }\end{array}$ \\
\hline \multicolumn{3}{|c|}{ Characteristics of VII technological way } \\
\hline $\begin{array}{l}\text { Cognitive and socio-human } \\
\text { technologies. The main } \\
\text { production factor is creative } \\
\text { intelligence }\end{array}$ & $\begin{array}{l}\text { "World vacuum control". New } \\
\text { forms of life on the planet. } \\
\text { Constructing a new social } \\
\text { reality }\end{array}$ & $\begin{array}{l}\text { Fusion technologies, } \\
\text { psi-technologies (advances in } \\
\text { modern psychology that } \\
\text { include new tools for human } \\
\text { management), bioenergy, } \\
\text { technologies related to morality } \\
\text { and responsibility. This way is } \\
\text { realized by means of hyper } \\
\text { intelligence, hyper knowledge, } \\
\text { hyper information, hyper } \\
\text { communication. "Subconscious } \\
\text { and mind games". It is } \\
\text { projected that there are five } \\
\text { cognitive technologies: } \\
\text { neuroimaging, cognotropic } \\
\text { drugs, cognitive assistants, } \\
\text { brain-machine interfaces and } \\
\text { artificial sensory organs }\end{array}$ \\
\hline
\end{tabular}


Table 2 Characteristic features of problems and risk management at different stages of green business in blue economy [16, p. 102-104; 10]

Possible life-cycle options "green business (WB)—innovation market (RI)—new products (NP)"

1

Preliminary diagnosis for questions major problems and risks of GB

\begin{tabular}{l|l}
\hline 1 (2) & 2 \\
\hline
\end{tabular}

1. WB growth is the embryonic state of RI-the technical idea of creating an NP

\section{2}

The problem is related to the need for rapid implementation of the technical idea and the emergence of NP in RI. The most significant risk is the mismatch of the expected and actual consumer response to the NP

2. WB growth-crystallization of RI - technical idea of creation of state of emergency

The problem is the same, but time is limited. Main risks are events that can slow down the process of RI production (counterparties, internal inconsistencies)

3. WB growth-RI growth-technical idea of creating an NP

The problem is the same, but the time resource is almost exhausted. Main risks are the same

4. WB growth-RI saturation-technical idea of creating a NP

Technical idea was "late"

5. WB growth-RI maturity-technical idea of creating a NP

6. WB growth-decline of RI-technical idea of creation of state of emergency

7. ST growth-embryonic state of $\mathrm{RI}$-development of NP

There are no visible problems. There is a good chance for the successful development of the ST in the future. Main risk is the mismatch of the expected and actual consumer response to the NP

8. WB growth-crystallization of $\mathrm{RI}-$ development of NP

9. WB growth-RI growth—NP development

10. WB growth-RI saturation-NP development

11. WB growth-RI maturity-NP development

12. WB growth—decline of RI-development of NP

13. ST growth-embryonic state of RI-exit of NP to RI

14. WB growth—crystallization of RI—output of NP on RI
There are no visible problems. However, the time resource for RI output is limited. Main risk is the same + events that can slow down the output of RI (counterparties, internal discrepancies)

Main problem is the limited time resource for the NP to enter RI. Main risks are the same

Development is "late". It is obvious that there are problems in management: marketing "sleeping", organization of the basic processes "limping". Main risk is the deterioration of financial condition

Has a chance for successful development of the WB in the future. Main risk is the mismatch of the expected and actual consumer response to the NP 
Table 2 (continued)

\begin{tabular}{|c|c|}
\hline $\begin{array}{l}\text { Possible life-cycle options "green business } \\
\text { (WB)_-innovation market (RI)—new products } \\
\text { (NP)" }\end{array}$ & $\begin{array}{l}\text { Preliminary diagnosis for questions major } \\
\text { problems and risks of GB }\end{array}$ \\
\hline 15. WB growth-RI growth-NP output to RI & $\begin{array}{l}\text { Unbeatable/wonderful! There are no } \\
\text { problems. Of paramount importance are the } \\
\text { risks of an internal nature: will the company } \\
\text { "drive" such rapid/rapid growth? }\end{array}$ \\
\hline $\begin{array}{l}\text { 16. WB growth-RI saturation- }-\mathrm{NP} \text { output at } \\
\text { RI }\end{array}$ & $\begin{array}{l}\text { Exit to RI NP "a little late". Underestimation } \\
\text { of management. Difficulties with the financial } \\
\text { state of the ST are possible }\end{array}$ \\
\hline 17. WB growth—RI maturity-NP output to RI & $\begin{array}{l}\text { The same, but financial problems can be more } \\
\text { serious }\end{array}$ \\
\hline $\begin{array}{l}\text { 18. WB growth—decline of RI-exit of NP on } \\
\text { RI }\end{array}$ & $\begin{array}{l}\text { The exit of the NP at RI was too late. Obvious } \\
\text { problems in management and marketing. } \\
\text { Financial losses can be critical to the ST }\end{array}$ \\
\hline $\begin{array}{l}\text { 19. WB growth—crystallization RI-sales } \\
\text { growth of innovation }\end{array}$ & $\begin{array}{l}\text { The situation is quite promising for the WB. } \\
\text { Main problem is to maintain a position in the } \\
\text { emerging market. Main risks are actions by } \\
\text { competitors }\end{array}$ \\
\hline 20. WB growth—RI growth—NP sales growth & $\begin{array}{l}\text { Fantastic situation! The problem is to save it. } \\
\text { Risks of internal character are most clearly } \\
\text { seen: in the part of the analysis of trends of } \\
\text { development of RI, as well as the organization } \\
\text { of the basic processes of ST }\end{array}$ \\
\hline $\begin{array}{l}\text { 21. WB growth-RI saturation—stable sale of } \\
\text { NP }\end{array}$ & $\begin{array}{l}\text { There are no obvious problems. Main risk is } \\
\text { the financial loss that can occur if the ST } \\
\text { "hangs" on RI with "old" product }\end{array}$ \\
\hline $\begin{array}{l}\text { 22. WB growth—RI maturity—stability of NP } \\
\text { sales }\end{array}$ & $\begin{array}{l}\text { The problem is the limited time available for } \\
\text { "production upgrades". Most important are } \\
\text { marketing risks as well as risks related to } \\
\text { reorganization of internal processes }\end{array}$ \\
\hline
\end{tabular}

the country. As a result, the enterprise contributes to the reduction of environmental pollution, but as a rule, not at will, but in accordance with the requirements of laws and regulations or regulations of world organizations.

The peculiarity of the second form of green production is that, in addition to minimizing the harmful environmental externalities from production activities, the enterprise has managers and employees forming an ecological consciousness, which is based on providing environmental needs not only for the modern generation, but also for creating favourable living conditions for the future by minimizing the environmental impact of production over the long term.

The third form of green production is manifested when the company, at its own discretion, switches to energy-efficient, environmentally friendly technologies for the 
Table 3 Previous recommendations regarding the control and quality management of green production at the stage of its growth [16, p. 102-104; 11]

Possible options for the life-stage ratio "green Previous recommendations production (DR)-innovation market (RI)—new products (NP)"

\begin{tabular}{|c|c|}
\hline 1 & 2 \\
\hline $\begin{array}{l}\text { 1. WB growth is the embryonic state of } \\
\mathrm{RI}-\text { the technical idea of creating an NP }\end{array}$ & \multirow{2}{*}{$\begin{array}{l}\text { Develop a rigorous timetable of activities to } \\
\text { ensure a rapid and efficient transition from a } \\
\text { technical idea to a serial issue of an NP. Clearly } \\
\text { motivate managers to implement the plan in } \\
\text { terms of time and quality }\end{array}$} \\
\hline $\begin{array}{l}\text { 2. WB growth-crystallization of } \\
\text { RI-technical idea of creation of state of } \\
\text { emergency }\end{array}$ & \\
\hline $\begin{array}{l}\text { 3. WB Growth-RI growth—technical idea } \\
\text { of Creating an NP }\end{array}$ & $\begin{array}{l}\text { Mobilize all resources for organizing activities } \\
\text { to bring the NP to RI }\end{array}$ \\
\hline $\begin{array}{l}\text { 4. WB growth-RI saturation-technical idea } \\
\text { of creating a NP }\end{array}$ & \multirow{3}{*}{$\begin{array}{l}\text { Use a technical idea for a second product that } \\
\text { addresses the needs of a more promising sector } \\
\text { of RI (second market niche) }\end{array}$} \\
\hline $\begin{array}{l}\text { 5. WB growth-RI maturity-technical idea } \\
\text { of creating a NP }\end{array}$ & \\
\hline $\begin{array}{l}\text { 6. WB growth-decline of RI-technical idea } \\
\text { of creation of state of emergency }\end{array}$ & \\
\hline $\begin{array}{l}\text { 7. ST growth-embryonic state of } \\
\text { RI-development of NP }\end{array}$ & $\begin{array}{l}\text { Perform continuous analysis of the state of RI. } \\
\text { Develop the programme for the fastest and most } \\
\text { effective product promotion }\end{array}$ \\
\hline $\begin{array}{l}\text { 8. WB growth—crystallization of } \\
\text { RI—development of NP }\end{array}$ & $\begin{array}{l}\text { Develop a timetable for activities that provide a } \\
\text { quick and effective transition from product } \\
\text { development to production. Clearly motivate } \\
\text { managers to implement the plan }\end{array}$ \\
\hline
\end{tabular}

9. WB growth-RI growth-NP development Mobilize all resources to accelerate the exit of the NP in RI

10. WB growth-RI saturation-NP development

11. WB growth-RI maturity-NP development

Use the development for a second NP focused on the needs of a more promising sector of RI (other market niche). Reorganize the main processes

12. WB growth-decline of $\mathrm{RI}$-development of NP

13. ST growth-embryonic state of RI-exit of NP to RI

Continuous monitoring of the consumer response to the state of emergency and the state

14. WB growth-crystallization of RI-output of NP on RI of RI. Develop a programme for the fastest and most effective promotion of NP

15. WB growth-RI growth-NP output to RI

16. WB growth-RI saturation-NP output at $\mathrm{RI}$

Analyse and refine basic processes. Pay more attention to discipline, responsibilities and responsibilities

17. WB growth-RI maturity-NP output to RI

The same NP + modified to more promising sectors RI (other niche market) 
Table 3 (continued)

\begin{tabular}{l|l}
\hline $\begin{array}{l}\text { Possible options for the life-stage ratio "green } \\
\text { production (DR)—innovation market } \\
\text { (RI)—new products (NP)" }\end{array}$ & Previous recommendations \\
\hline $\begin{array}{l}\text { 18. WB growth—decline of RI—exit of NP } \\
\text { on RI }\end{array}$ & $\begin{array}{l}\text { Reorganize the management system and main } \\
\text { processes of the EE. Modify NP for a more } \\
\text { promising sector of RI (other market niche) }\end{array}$ \\
\hline $\begin{array}{l}\text { 19. WB growth—crystallization RI—sales } \\
\text { growth of innovation }\end{array}$ & $\begin{array}{l}\text { To carry out constant analysis of the state of RI, } \\
\text { and especially, the actions of competitors. } \\
\text { Ensure the readiness of the EE (in terms of } \\
\text { organizing major processes) for its potential } \\
\text { growth }\end{array}$ \\
\hline $\begin{array}{l}\text { 20. WB growth-RI growth—NP sales } \\
\text { growth }\end{array}$ & $\begin{array}{l}\text { Constantly analyse the state of RI. Ensure that } \\
\text { the VP is ready to move to another product line } \\
\text { or to another sector (niche) of RI }\end{array}$ \\
\hline $\begin{array}{l}\text { 21. WB growth-RI saturation—-stable sale } \\
\text { of NP }\end{array}$ & $\begin{array}{l}\text { Develop a production upgrade programme: } \\
\text { move to another product line or to other sectors } \\
\text { (niches) of RI }\end{array}$ \\
\hline $\begin{array}{l}\text { 22. WB growth-RI maturity—-stability of } \\
\text { NP sales }\end{array}$ & Implement the production upgrade programme \\
\hline
\end{tabular}

production of goods and services and promotes environmental improvements through the use in the process of activity of methods and raw materials that minimize the environmental-destructive impact on the environment and lead to improved living conditions [13].

Green technologies are production processes that are nature-friendly and produce a product that meets high quality standards. For example, the largest vehicle companies have turned their attention to hybrid and electric cars, ecotires and ecogasoline, which are still in high demand today. One should not ignore the fact that in these areas there is an active cooperation between business and science.

Scientists from different universities in the world are opening up new opportunities in the use of solar panels, growing organic crops and creating an "eco-culture" [14]. Rating of the most promising green business ideas that allow you to join the environmental market and a basis for the formation of a blue economy in Ukraine is presented in Table 4.

\section{Conclusions}

Key features of the future patterns of development of the blue economy in Ukraine should be:

- Institutional order of the cluster structure based on innovative hubs;

- Direct communication between its members;

- A collective way of creating innovation; 
Table 4 Rating of the most promising green business ideas that allow you to join the green market and lay the foundations for becoming a blue economy in Ukraine (compiled by authors based on source 16)

Green business idea of green direction

The content and overall characteristics of green business idea that underlies blue economy

Eco-consulting services

Ideal for those who are well versed in green technology.

Companies operating in the sector provide

environmental expertise for residential buildings, office space, and are developing options for improving eco-equipment, ranging from energy-efficient technologies to waste management programmes. In order to gain the trust of potential clients, you need to get a certificate, better international, that allows such activities

Bicycle repair

This service is in dire demand in a number of CIS countries. Not only the desire to preserve the environment, but also more rational arguments (high prices for gasoline, endless traffic jams and accidents) make citizens abandon cars. In addition, having ridden a bicycle about ten kilometres away, you do not have to go to the fitness room, so you can save money and burn calories, which will not be unnecessary. For these reasons, there is a need to open bicycle repair centres

\begin{tabular}{l|l}
\hline Cleaning of ventilation systems & Provides services that improve the energy efficiency of
\end{tabular} buildings. The fact is that dust and other small particles in any case enter the ventilation systems, but you can get rid of them. This may come in handy for a company that will show you how to save money on gas and electricity. Potential clients can certainly be allergy sufferers: they are always willing to pay a lot of money just to get rid of the allergens

Growing vegetables and fruits

This industry clearly demonstrates the desire of many to eat properly, favouring those fruits and vegetables offered not by large companies but by small farms. It is important that there are certificates that confirm that no chemicals were used when growing the crops. You should also be prepared for the approval of such activities to be agreed with the local authorities

Release of organic cosmetics

A real hit in today's market. Nowadays, girls and women are striving not only to be beautiful, using a huge amount of products every day, but also to want cosmetics to be safe for the skin. At the same time, most beauties simply do not have the time to prepare their own scrub or balm, so it is much easier to buy the finished product

Furniture restoration

A service that is not cheap but is of interest to many.

The content of the service is to "revive" old furniture, which may have been inherited from grandparents and which are just so easy to say goodbye to 
Table 4 (continued)

\begin{tabular}{l|l}
\hline Green business idea of green direction & $\begin{array}{l}\text { The content and overall characteristics of green } \\
\text { business idea that underlies blue economy }\end{array}$ \\
\hline Eco-cleaning of the house & $\begin{array}{l}\text { Actual service for people who are constantly employed. } \\
\text { Cleaning up with clean, non-chemical cleaners is a } \\
\text { difficult job, but it is essential for families with small } \\
\text { children or allergic family members }\end{array}$ \\
\hline
\end{tabular}

- An effectively functioning harmonization institute;

- Structure of production of V and VI technological structures.

The strategic priorities for the development of green production of innovative type in the course of R\&D include: development of new technologies of energy transportation, introduction of resource-saving technologies, modernization of power plants and technological updating of the agro-industrial complex, high-tech updating of machine and instrument making, systematic modernization of health care.

\section{References}

1. Create your own infographics (2019). Available at http://www.liga.net/infografica/336 825_ukraina-opustilas-v-reytinge-samykh-konkurentosposobnykh-ekonomik.htm (Accessed 19 January 2019)

2. Global innovation index. Analysis (2018). Explore the interactive database of the gii 2018 indicators. Available at https://www.globalinnovationindex.org/analysis-indicator (Accessed 19 December 2018)

3. National report of Ministry of Economic Development and Trade of Ukraine (2017) Tsili Staloho Rozvytku: Ukraina [Sustainable Development Goals: Ukraine]. Kyiv, Ukraine

4. EUROPE2020 (2019) A strategy for smart, sustainable and inclusive growth. Available at http://eur-lex.europa.eu/legal-content/en/ALL/?uri=CELEX\%3A52010DC2020 (Accessed 12 January 2019)

5. Gryunvald M, Merts A, Rikhter K, Shults A (2018) Technological transfer. Tekhnolohichnyi transfer, Available at http://www.nw-innovations.ru/analitika/orgformi/list1/text/tema2.shtml (Accessed 19 May 2018)

6. Fronshtein NM (1999) Transfer tekhnolohii ta efektyvne vprovadzhennia innovatsii [Technology transfer and effective implementation of innovations]. Russia, Moscow

7. Mukhopad VI (2002) Litsenzovana torhivlia: marketynh, tsinoutvorennia, upravlinnia [Licensed trade: marketing, pricing, management], 2nd edn. INITs, Moscow, Russia

8. Green Business (2019). Available at https://uk.wikipedia.org/wiki/Зелений_бізнес (Accessed 15 January 2019)

9. Kyiv International Economic Forum (2018) Eight state incentives for innovation are world-wide experience. Available at http://forumkyiv.org/uk/analytics/visim-derzhavnih-stimuliv-dlya-roz vitku-innovacij-svitovij-dosvid (Accessed 8 January 2019)

10. Our Common Future (2019). Available at https://en.wikipedia.org/wiki/Our_Common_Future (Accessed 14 January 2019)

11. Triple bottom line (2019). Available at https://en.wikipedia.org/wiki/Triple_bottom_line (Accessed 18 January 2019)

12. Umbrella patenting (2019) Umbrella patenting. Available at http://forum.triz-guide.com/vie wtopic.php? $\mathrm{p}=858$ (Accessed 10 January 2019) 
13. Lanovenko OG, Ostapishina OO (2013) Ecological business. Dictionary-a guide to ecology: a teaching method. Kherson: PP Vyshemirsky VS, S. 78-79

14. Yurinova I (2019) Green production: best ideas for eco-business development in the world. Available at http://prostir.co.ua/vyrobnytstvo-najkraschi-rozvytku-4466/ (Accessed 12 January 2019)

15. Krasnoshchekov PA (2008) Structure of technological style [Innovations]. 2(112):S.56-59

16. Medvedeva AM (2011) Blitz analysis of a growing company and risk management [MIR: Modernization. Innovation Development], 3(7):S.100-104 